\title{
Human Liver Aldehyde Oxidase: Differential Inhibition of Oxidation of Charged and Uncharged Substrates *
}

\author{
David G. Јон NS \\ (From the Department of Pharmacology, Yale University School of Medicine, \\ New Haven, Connecticut)
}

\begin{abstract}
Summary. Human liver aldehyde oxidase (aldehyde: $\mathrm{O}_{2}$ oxidoreductase, EC 1.2.3.1) has been purified 60-fold and some of its properties studied. Like aldehyde oxidase from other mammalian species, human liver aldehyde oxidase is an enzyme with dual substrate specificity, possessing the ability to catalyze not only the oxidation of aldehydes to the corresponding carboxylic acids, but also the hydroxylation of a number of nonaldehydic heterocyclic compounds; its relative activity towards the latter group of substrates is low, however, when compared with that of liver aldehyde oxidase from rabbit and guinea pig. When the aromatic aldehyde benzaldehyde is used as substrate, human liver aldehyde oxidase, like the rabbit enzyme, is strongly inhibited by menadione, estradiol-17 $\beta$, antimycin $\mathrm{A}$, Triton $\mathrm{X}-100$, and $N$-alkylphenothiazines; the human enzyme differs from the rabbit enzyme, however, in being relatively insensitive to oligomycin and Amytal. Like the rabbit enzyme, the human enzyme can catalyze the 3-hydroxylation of phenazine methosulfate (PMS) and the 6-hydroxylation of $N$-methylnicotinamide (NMN). With the rabbit enzyme, however, the aerobic hydroxylation of these substrates proceeds by a conventional mechanism, while with the human enzyme, the aerobic hydroxylation of PMS and NMN is anomalous in that the reaction is inhibited only by agents with affinity for the substrate-binding site, such as cyanide and $N$-alkylphenothiazines, and not by agents which inhibit the "internal electron transport chain" of the enzyme, such as menadione and diethylstilbestrol. This mode of oxidation appears to be unique to substrates with a positively charged quaternary nitrogen; the hydroxylation of other nonaldehydic heterocyclic substrates for the human enzyme is sensitive to conventional aldehyde oxidase inhibitors.
\end{abstract}

\section{Introduction}

The enzyme hepatic aldehyde oxidase (aldehyde: $\mathrm{O}_{2}$ oxidoreductase, EC 1.2.3.1) was first described by Gordon, Green, and Subrahmanyan (1). They demonstrated that the enzyme was a flavoprotein distinct from the rather similar enzyme xanthine oxidase (xanthine: $\mathrm{O}_{2}$ oxidoreduc-

* Submitted for publication 18 April 1967; accepted 25 May 1967.

This work was supported by grants CA-02817 and CA- 08010 from the U. S. Public Health Service.

Address requests for reprints to Dr. David G. Johns, Department of Pharmacology, Yale University School of Medicine, 333 Cedar Street, New Haven, Conn. 06510. tase, EC 1.2.3.2) ; like xanthine oxidase, however, it could catalyze the oxidation of a variety of aliphatic and aromatic aldehydes. The source of enzyme for these early studies was hog liver. In 1946, Knox (2) demonstrated that aldehyde oxidase from rabbit liver possessed the ability to catalyze not only the oxidation of aldehydes, but also the hydroxylation of a number of nonaldehydic heterocyclic compounds, e.g., $N$-methylnicotinamide and quinine. He noted also that the ability of the rabbit liver enzyme to catalyze the oxidation of the latter group of substrates was much greater than that of aldehyde oxidase from other mammalian species. Mahler, Mackler, 
Green, and Bock (3) further purified the hog liver enzyme, and demonstrated the presence of molybdenum and iron. Hurwitz (4) demonstrated the ability of rabbit liver aldehyde oxidase to catalyze the oxidation of pyridoxal, and described a number of properties of the enzyme, in particular, its inhibition by cyanide and $p$-hydroxymercuribenzoate. Rajagopalan, Fridovich, and Handler (5), and Rajagopalan and Handler $(6,7)$ have published a detailed and comprehensive study of the rabbit liver enzyme; they prepared rabbit liver aldehyde oxidase of greater than $90 \%$ purity and demonstrated the presence of coenzyme $Q_{10}$ in the purified enzyme.

Our attention was directed to this enzyme by our finding that, in several species, it was the previously unidentified catalytic agent responsible for the 7-hydroxylation (8) and consequent biological inactivation (9) of the anti-tumor agent 3',5'-dichloromethotrexate, a 6-substituted 2,4-diaminopteridine (10). We subsequently noted that the rabbit liver enzyme could catalyze also the oxidation of several pyrimidines (11) and purines (12) of pharmacologic interest. Since the rabbit liver enzyme has much greater catalytic activity towards nonaldehydic heterocyclic compounds than does aldehyde oxidase from other species, it appeared that information on the properties of human liver aldehyde oxidase was necessary before these findings could be extended to man. It was found, however, that the human enzyme had not been described, despite the possible significance of this enzyme both in the oxidation of aldehydes arising in the course of intermediary metabolism (particularly in the metabolism of ethanol and its congeners) and in the hydroxylation of pharmacologically active heterocyclic compounds. Studies concerned particularly with the sensitivity to inhibitors and with the substrate specificity of human liver aldehyde oxidase were therefore carried out, and are described below.

\section{Methods}

Gifts of the following compounds are gratefully acknowledged: trifluoperazine, trimeprazine, chlorpromazine (CPZ), and $N$-methylphenothiazine from Dr. E. J. Van Loon, Smith, Kline \& French Laboratories, Philadelphia, $\mathrm{Pa}$; promethazine and promazine from Dr. F. E. Hamerslag, Wyeth Laboratories, Philadelphia, Pa.; 3',5'dichloromethotrexate (DCM) from Dr. J. M. Rueg- segger, Lederle Laboratories Div., American Cyanamid Co., Pearl River, N. Y.; 2-hydroxy-5-fluoropyrimidine from Dr. Z. Buděšinský of the Research Institute of Pharmacy and Biochemistry, Prague; 4-hydroxypyrazolo $[3,4-d]$ pyrimidine from Dr. G. B. Elion, Burroughs Wellcome \& Co., Tuckahoe, N. Y.; and disulfiram from Ayerst Laboratories, New York, N. Y. 2,6-Dichlorophenolindophenol (DCIP), $\alpha, \alpha$-dipyridyl, and DEAEcellulose were obtained from the Eastman Kodak Co., Rochester, N. Y.; phenazine methosulfate (PMS), Nmethylnicotinamide (NMN), diethylstilbestrol, coenzyme $Q_{10}$, progesterone, and $p$-chloromercuribenzoate from Calbiochem, Los Angeles, Calif.; oligomycin, flavin adenine dinucleotide (FAD), flavin adenine mononucleotide (FMN), quinacrine, and ammonium sulfate (enzyme grade) from Mann Research Laboratories, Inc., New York, N. Y.; estradiol-17 $\beta$ from California Foundation for Biochemical Research, Los Angeles, Calif.; benzaldehyde, acetaldehyde, propionaldehyde, methanol, potassium cyanide, ammonium chloride, and Versene $\mathrm{Fe}-3$ from Fisher Scientific Company, Pittsburgh, Pa.; Amytal and diethyldithiocarbamic acid from K \& K Laboratories, Inc., Plainview, N. Y.; $o$-chlorobenzaldehyde from Paragon Testing Laboratories, Orange, N. J.; $\boldsymbol{o}$-nitrobenzaldehyde from Matheson, Coleman, \& Bell, E. Rutherford, N. J.; menadione and pyridoxal hydrochloride from Nutritional Biochemicals Corporation, Cleveland, Ohio; antimycin A, nicotinamide adenine dinucleotide (NAD), nicotinamide adenine dinucleotide reduced (NADH), nicotinamide adenine dinucleotide phosphate (NADP), nicotinamide adenine dinucleotide phosphate reduced (NADPH), from Sigma Chemical Co., St. Louis, Mo.; Triton X-100 from Rohm \& Haas Co., Philadelphia, Pa.; and frozen mature rabbit liver from Pel-Freez Biologicals, Inc., Rogers, Arkansas.

Enzyme assays. Spectrophotometric assay methods were employed throughout. For assays at a single wavelength, a Gilford multiple sample absorbance recorder with a Beckman DU monochromator was used; a Cary 15 recording spectrophotometer equipped with a $0-0.1$ OD and 0-1.0 OD slide wire was used for serial assays requiring complete ultraviolet absorption spectra.

(a) Benzaldehyde as substrate. Examination of the ultraviolet absorption spectra of benzaldehyde and of benzoate at equimolar concentrations at $\mathrm{pH} 7.8$ revealed that the latter compound lacked the strong absorption maximum of benzaldehyde at $249 \mathrm{~m} \mu(\Sigma \max =17,540)$ (Fig. 1). It therefore appeared possible that aldehyde oxidase activity could be assayed by monitoring the decrease in absorption at $249 \mathrm{~m} \mu$ consequent upon the oxidation of benzaldehyde to benzoate. Serial spectra of the enzymic conversion of benzaldehyde as catalyzed by the rabbit enzyme are shown in Fig. 2; details of the assay are given in the legend for the figure. In adapting the assay to the Gilford multiple sample absorbance recorder, the $0-0.250$ OD scale was used, and a cuvette with all constituents of the reaction except benzaldehyde used as a blank. Sample cuvettes contained, in addition, $5.6 \times 10^{-5} \mathrm{M}$ benzaldehyde. Because of the high protein levels required in the blank and sample cuvettes for 


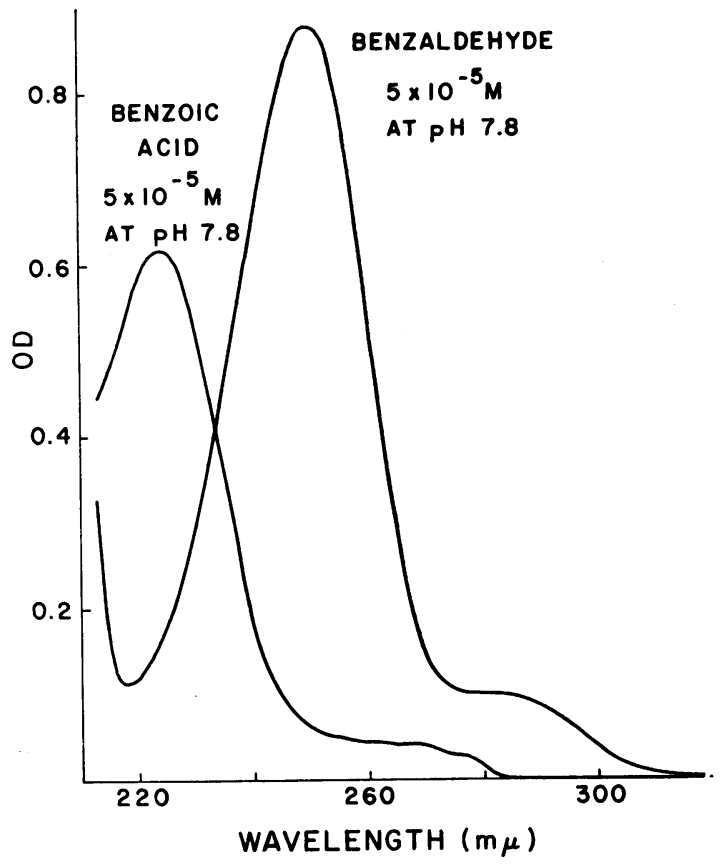

Fig. 1. Ultraviolet absorption SPECTRA OF BENZALDEHYDE AND BENZOIC ACID IN SODIUM PHOSPHATE BUFFER AT $\mathrm{PH} 7.8$.

measurable activity at early stages of the purification of the human enzyme, proper adjustment of the deuterium lamp mirror for maximum light intensity at $249 \mathrm{~m} \mu$ was found to be essential. The assay could be performed successfully with two randomly selected monochromators requiring slit widths of 0.35 and $0.42 \mathrm{~mm}$, respectively, when blanked against distilled water at $249 \mathrm{~m} \mu$; the assay was not practicable with a third monochromator requiring a slit width of $1.02 \mathrm{~mm}$ when blanked under the same conditions. Rates were measured over a period of $2 \mathrm{~min}$; detailed assay conditions are described in later sections.

(b) PMS as substrate. The spectra of PMS and its oxidation product, methylphenazine-3-one, have been published by Rajagopalan and Handler (13). In the routine assay used here, the sample cuvettes contained PMS, $0.5 \mu$ mole, sodium phosphate buffer, $\mathrm{pH} 7.8,100$ $\mu$ moles, Versene $\mathrm{Fe}-3,15 \mu \mathrm{g}$, ammonium chloride, 100 $\mu$ moles, and enzyme solution, containing varying amounts of protein, $0.1 \mathrm{ml}$; total volume was $1 \mathrm{ml}$. The increase in absorption at $520 \mathrm{~m} \mu$ consequent on the oxidation of PMS was monitored at $23^{\circ} \mathrm{C}$ over a period of $4 \mathrm{~min}$ with the Gilford multiple sample absorbance recorder; controls without substrate and without enzyme were included in all assays. A molar extinction coefficient of 11,700 for methylphenazine-3-one at $520 \mathrm{~m} \mu$ was assumed (13). Fresh PMS solutions were prepared hourly, as accumulation of enzyme-inhibitory PMS oxidation products was noted in PMS stock solutions exposed to air. (c) Dichlorophenolindophenol (DCIP) as electron acceptor. The enzyme assays described above were performed aerobically, with molecular oxygen as electron acceptor; reaction rates were determined from disappearance of substrate, in the case of benzaldehyde, or appearance of product, in the case of PMS. With aliphatic aldehyde substrates, however, conversion of substrate to product was not accompanied by measurable spectral changes. In these instances, DCIP, rather than oxygen, was used as electron acceptor, and the rate of reaction followed by measuring the rate of reduction of this compound at $600 \mathrm{~m} \mu$. In these assays, $0.25 \mathrm{ml}$ of a DCIP solution of $10 \mathrm{mg} / 100 \mathrm{ml}$ was added to the cuvette; sodium phosphate, Versene $\mathrm{Fe}-3$, and ammonium chloride concentrations were the same as in the PMS assay. Rates were measured over a period of $4 \mathrm{~min}$ at $23^{\circ} \mathrm{C}$, and a molar extinction coefficient of 19,100 was assumed for DCIP (14).

(d) Slowly oxidized substrates. The enzymic conversions of 2-hydroxy-5-fluoropyrimidine to 5-fluorouracil (11), DCM to 7-hydroxyDCM, and NMN to NMN-6pyridone were followed by serial ultraviolet absorption

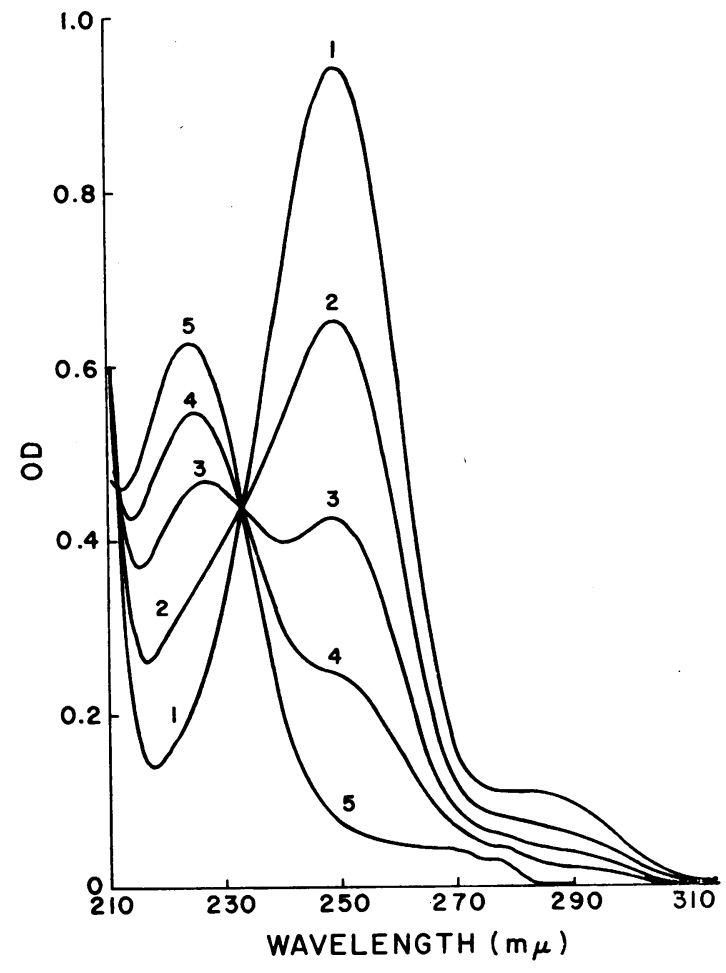

Fig. 2. ENZYMic CONVERSION OF BENZALDEHYDE TO BENZOATE BY RABBIT LIVER ALDEHYDE OXIDASE. The reference cuvette contained sodium phosphate buffer, $\mathrm{pH} 7.8$, $500 \mu$ moles, Versene $\mathrm{Fe}-3,20 \mu \mathrm{g}$, and rabbit liver aldehyde oxidase, $45 \mu \mathrm{g}$, in a total volume of $3 \mathrm{ml}$. The sample cuvette contained the same constituents, plus benzaldehyde, $0.17 \mu$ mole. Spectra were recorded at 4-min intervals. 
spectra, with the Cary 15 recording spectrophotometer. Reference cuvettes contained sodium phosphate buffer, $\mathrm{pH}$ 7.8, $500 \mu$ moles (for DCM, buffer of $\mathrm{pH} 6.9$ was used), Versene $\mathrm{Fe}-3,20 \mu \mathrm{g}$, ammonium chloride, $600 \mu$ moles, and enzyme, in a total volume of $3 \mathrm{ml}$. The sample cuvette contained the same constituents plus substrate. Since the rate of hydroxylation of these three substrates was slow when the human enzyme was used, maximum possible amounts of enzyme protein were added to reference and sample cuvettes, compatible with accurate recording of spectra of substrate and product.

Partial purification of rabbit liver aldehyde oxidase. Aldehyde oxidase was purified approximately 90 -fold from rabbit liver by ammonium sulfate fractionation and chromatography on Sephadex G-75 and DEAE-cellulose, as previously described (10). Enzyme activity was assayed with DCM as substrate, and protein was determined by the method of Waddell (15).

Partial purification of human liver aldehyde oxidase. It early became apparent that fresh human liver biopsy material would yield insufficient enzyme for comprehensive studies. Previous studies with the rabbit, mouse, guinea pig, and monkey enzymes indicated, however, that aldehyde oxidase was recoverable from the livers of these species with no detectable alteration in yield or in properties, as long as $24 \mathrm{hr}$ after death, provided that the livers were stored cold (but not frozen) during this interval. For partial purification of the human enzyme, therefore, postmortem human livers were obtained at time of autopsy, within $4 \mathrm{hr}$ after death, with the cooperation of the Department of Pathology, Yale University School of Medicine. Livers from patients with a history of hepatic disease, and livers with gross pathological changes, were excluded; otherwise no selection was made. A total of nine livers was used in this study, from three female and six male subjects ranging in age from 4 to $71 \mathrm{yr}$. No marked variation in enzyme activity was noted among livers from which enzyme was prepared on the day of collection; two livers which were frozen after collection and used for enzyme preparation some weeks later were found to have much lower enzyme activity. A similar observation of low yield of aldehyde oxidase from horse liver after freezing and thawing was reported by Carpenter (16).

Some studies were repeated with enzyme from fresh wedge biopsy material obtained at laparotomy; no differences were noted from enzyme obtained from necropsy liver.

Livers were homogenized for $1 \mathrm{~min}$ in 2.5 volumes of $0.05 \mathrm{M}$ sodium phosphate buffer, $\mathrm{pH} 7.8$, containing Versene $\mathrm{Fe}-3,0.005 \%$, the homogenate contrifuged at 14,600 $g$ at $4^{\circ} \mathrm{C}$ for $30 \mathrm{~min}$, and an aliquot of the supernatant fraction removed for determination of enzyme activity. The supernatant was then heated with continuous stirring for $10 \mathrm{~min}$ at $60^{\circ} \mathrm{C}$ in a water bath. Heat-precipitated protein was removed by centrifuging at $14,600 \mathrm{~g}$ for $30 \mathrm{~min}$, the supernatant fraction collected, and sufficient saturated ammoniacal ammonium sulfate solution added to give $45 \%$ saturation; saturated ammoniacal ammonium sulfate solution was prepared by adding $60 \mathrm{ml}$ of concentrated (29\%) ammonium hydroxide solution to $940 \mathrm{ml}$ of saturated ammonium sulfate solution. The supernatant solution was allowed to stir slowly at room temperature for $30 \mathrm{~min}$, and the precipitate recovered by centrifuging as above. The precipitate was extracted with sufficient ammoniacal ammonium sulfate solution of $30 \%$ saturation to give a protein concentration in the supernatant of approximately $25 \mathrm{mg} / \mathrm{ml}$ (in a typical preparation, this required $120 \mathrm{ml}$ of ammonium sulfate solution when liver of starting weight $1300 \mathrm{~g}$ was used). The supernatant was recovered by centrifugation, and the precipitate subjected to successive reextractions with ammoniacal ammonium sulfate of $15 \%$ saturation, and with distilled water. Typically, most of the aldehyde oxidase activity was present in the $15-30 \%$ ammonium sulfate fraction, although activity was usually detectable in the $0-15 \%$ ammonium sulfate fraction; if the specific activity of the latter approached that of the $15-30 \%$ fraction, the two fractions were combined before the next step, which otherwise was performed on the $15-30 \%$ ammonium sulfate fraction alone.

In earlier runs, salts and diffusible low molecular weight compounds were removed at this stage of the purification by overnight dialysis of the $15-30 \%$ ammonium sulfate fraction against distilled water at $4^{\circ} \mathrm{C}$; it was later found, however, that an alternate procedure, desalting by gel filtration through Sephadex G-75, resulted in less loss of enzyme activity then did overnight dialysis, possibly because gel filtration could be carried out much more rapidly. In a typical run, enzyme solution containing $320 \mathrm{mg}$ of protein was applied to a Sephadex G-75 column, $2 \times 18 \mathrm{~cm}$, previously washed for several hours with distilled water. The protein solution obtained from the Sephadex column was then applied to a column of DEAE-cellulose, which had been preequilibrated with distilled water, and eluted stepwise with Trischloride buffers, $\mathrm{pH} 7.5$, of concentrations $0.05,0.15,0.25$, and $0.50 \mathrm{~mole} /$ liter. In a representative run, $280 \mathrm{mg}$ of protein was applied to a DEAE-cellulose column of $2 \times$ $18 \mathrm{~cm}$; the enzyme activity typically appeared in the $0.25 \mathrm{~m}$ Tris effluent, although activity was often detectable in the $0.15 \mathrm{M}$ Tris effluent also.

The $0.25 \mathrm{M}$ Tris effluent from several such columns was combined and concentrated osmotically to 0.1 volume by applying powdered sucrose to the external surface of a dialysis bag containing the protein solution. Protein was precipitated again from the concentrated Tris effluent by adding saturated ammoniacal ammonium sulfate solution until $45 \%$ saturation was reached. The precipitated protein was redissolved in distilled water to give a solution of approximately $5 \mathrm{mg} / \mathrm{ml}$. The purification procedure for the human enzyme is summarized in Table I.

For determination of the specific activity of the fractions obtained during purification, the benzaldehyde assay described above was used. Before assay, aliquots from the early fractions were subjected to recentrifugation at $105,000 \mathrm{~g}$ for $1 \mathrm{hr}$ in a Spinco model L centrifuge; 
TABLE I

Fartial purification of human liver aldehyde oxidase

\begin{tabular}{|c|c|c|c|c|c|c|}
\hline Fraction & $\begin{array}{c}\text { Total } \\
\text { volume }\end{array}$ & $\begin{array}{c}\text { Total } \\
\text { protein }\end{array}$ & $\begin{array}{c}\text { Total } \\
\text { activity }\end{array}$ & $\begin{array}{l}\text { Specific } \\
\text { activity }\end{array}$ & Yield & Purification \\
\hline & $m l$ & $m g$ & units* & units/mg & $\%$ & -fold \\
\hline Supernatant from crude homogenate & 4000 & 260,000 & 3900 & 0.015 & & \\
\hline $\begin{array}{l}\text { Supernatant from crude homogenate } \\
\text { after heat treatment }\left(60^{\circ} \mathrm{C} \text { for }\right. \\
10 \mathrm{~min})\end{array}$ & 3550 & 124,000 & 3100 & 0.025 & 79 & 1.7 \\
\hline Ammonium sulfate $(15-30 \%)$ & 140 & 5,379 & 1824 & 0.339 & 47 & 23 \\
\hline $\begin{array}{l}\text { DEAE-cellulose (precipitated with } \\
\text { ammonium sulfate and redissolved) }\end{array}$ & 262 & 1,362 & 1248 & 0.915 & 32 & 61 \\
\hline
\end{tabular}

* One unit $=$ amount of enzyme producing $\Delta 249 \mathrm{~m} \mu$ of 1 optical density unit per $10 \mathrm{~min}$ at $23^{\circ} \mathrm{C}$ with benzaldehyde, $5.6 \times 10^{-5}$ mole per liter, as substrate. In all assays, activity was determined from initial rates.

assays were carried out on the supernatant. ${ }^{1}$ The other assay methods described above, although of value with the partially purified enzyme, were not useful for determining over-all fold purification, since they were not applicable to the determination of aldehyde oxidase activity in supernatants from crude homogenates: the DCIP assay gave a high blank rate in the absence of substrate, ${ }^{2}$ while the PMS assay gave a spuriously high rate with crude homogenates, due possibly to the presence of one or more enzymes, in addition to aldehyde oxidase, with PMS oxidase activity. This additional PMS oxidase activity could not be inhibited by cyanide, quinacrine, or methanol, and therefore was not attributable to alde-

1 Rajagopalan, Fridovich, and Handler (5) have shown rabbit liver aldehyde oxidase to be a supernatant enzyme; the hog liver enzyme appears to be mitochondrial, but is readily released into the supernatant fraction during homogenization (17).

${ }^{2} \mathrm{~A}$ similar observation was reported by Palmer, with the hog liver enzyme (18). hyde oxidase (5). The benzaldehyde oxidase activity of the crude fractions, on the other hand, was completely inhibited by cyanide $\left(1 \times 10^{-4}\right.$ mole per liter $)$, diethylstilbestrol $\left(4 \times 10^{-5}\right.$ mole per liter $)$, and menadione $(2.5 \times$ $10^{-5}$ mole per liter), and is therefore tentatively attributable to aldehyde oxidase; the validity of these assumptions is discussed in a later section.

The rapid assay methods used in the purification of the rabbit liver enzyme by Rajagopalan, Fridovich, and Handler (5) (the conversion of NMN to its 6-pyridone) and by the present author (10) (the conversion of DCM to 7-hydroxyDCM) were of no value in determining fold purification of the human enzyme: the rates of oxidation were too low to be measured in crude fractions, and the conversion of these substrates could be demonstrated spectrophotometrically only with partially purified human liver aldehyde oxidase.

Most of the studies described below were carried out both with human liver aldehyde oxidase purified 20 - to 30 -fold (the "15-30\% ammonium sulfate enzyme") and

TABLE II

Effect of inhibitors on the conversion of benzaldehyde to benzoate by human liver aldehyde oxidase*

\begin{tabular}{|c|c|c|}
\hline & Inhibitor concentration & Inhibition \\
\hline $\begin{array}{l}\alpha, \alpha \text {-Dipyridyl } \\
\text { Chlorpromazine } \\
\text { Diethylstilbestrol } \\
\text { Progesterone } \\
p \text {-Hydroxymercuribenzoate } \\
\text { Oligomycin } \\
\text { Quinacrine } \\
\text { Estradiol-17 } \beta \\
\text { Methanol } \\
\text { Potassium cyanide } \\
\text { Antimycin A } \\
\text { Triton X-100 } \\
\text { Menadione } \\
\text { Testosterone }\end{array}$ & $\begin{array}{l}1 \times 10^{-4} \text { mole per liter } \\
5 \times 10^{-6} \text { mole per liter } \\
4 \times 10^{-7} \text { mole per liter } \\
6 \times 10^{-5} \text { mole per liter } \\
2 \times 10^{-5} \text { mole per liter } \\
60 \mu \mathrm{g} / \mathrm{ml} \\
5 \times 10^{-5} \text { mole per liter } \\
8 \times 10^{-8} \text { mole per liter } \\
0.3 \text { mole per liter } \\
1 \times 10^{-4} \text { mole per liter } \\
8 \times 10^{-4} / \mathrm{ml} \\
1.5 \times 10^{-5} \text { mole per liter } \\
6 \times 10^{-5} \text { mole per liter }\end{array}$ & $\begin{array}{l}\% \\
53 \\
51 \\
43 \ddagger \\
71 \S \\
88 \\
28 \\
51 \\
50 \ddagger \\
67 \\
66 \\
46 \ddagger \\
65 \\
55 \\
44\end{array}$ \\
\hline
\end{tabular}

* Sample cuvettes contained benzaldehyde, $0.057 \mu$ mole, sodium phosphate buffer, $\mathrm{pH} 7.8,100 \mu$ moles, Versene Fe-3, $15 \mu \mathrm{g}$, ammonium chloride, $100 \mu$ moles, and enzyme solution, $0.03 \mathrm{ml}$, in a total volume of $1 \mathrm{ml}$. Initial rates were measured, except where otherwise noted.

$\ddagger$ At the end of $5 \mathrm{~min}$.

$\S$ At the end of $3 \mathrm{~min}$. 
40- to 60-fold (the "DEAE-cellulose enzyme"). No significant differences were noted in the human enzyme at these two stages of purification.

\section{Results}

\section{Inhibitors of benzaldehyde oxidation}

Benzaldehyde $\left(5.6 \times 10^{-5}\right.$ mole per liter) was used as substrate, and enzyme activity monitored at $23^{\circ} \mathrm{C}$ by measuring the rate of conversion to benzoate at $249 \mathrm{~m} \mu$ (see above).

(a) Steroids as inhibitors. As shown in Table II, the oxidation of benzaldehyde to benzoate by human liver aldehyde oxidase was inhibited by a variety of agents: the inhibition by the steroid estradiol- $17 \beta$ and the nonsteroidal estrogen diethylstilbestrol was particularly marked (Fig. 3). Estradiol-17 $\beta$ is the most potent inhibitor of human liver aldehyde oxidase found in the present studies; $50 \%$ inhibition of the rate of oxidation was noted at an estradiol concentration of $8 \times 10^{-8}$ mole per liter, when control and inhibited rates were measured $5 \mathrm{~min}$ after the start of the reaction. The slow development of maximal inhibition at low estradiol concentrations is apparently due to a slow rate of binding of the steroid to the enzyme: when estradiol $\left(8 \times 10^{-8}\right.$ mole per liter $)$

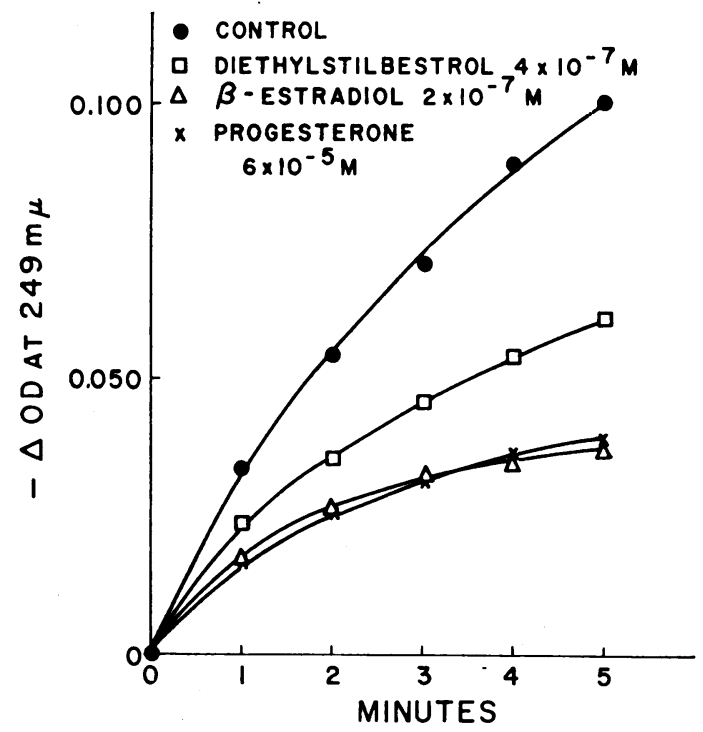

Fig. 3. INHIBITION OF HUMAN LIVER ALDEHYDE OXIDASE BY ESTROGENS AND PROGESTERONE. The rate of oxidation of benzaldehyde $\left(5.6 \times 10^{-5}\right.$ mole per liter) was followed by the change in optical density at $249 \mathrm{~m} \mu$; reaction conditions were identical to those given in Table VII.<smiles></smiles>

N - METHYLPHENAZINE (PMS)<smiles>CN(C)CCN(C)c1ccccc1Sc1ccc(Cl)cc1</smiles>

CHLORPROMAZINE (CPZ)

Fig. 4. Structural Formulas of N-MEthylphenaZINE AND CHLORPROMAZINE.

and enzyme were preincubated for $5 \mathrm{~min}$ before the reaction was started by adding substrate, maximal inhibition was noted at zero time. The situation thus differs from that seen with antimycin A, where preincubation did not shorten the period required for maximal inhibition to develop (see below).

The nonphenolic steroids progesterone and testosterone were much weaker inhibitors of the enzyme.

(b) N-alkylphenothiazines as inhibitors. The possible activity of $N$-alkylphenothiazines as inhibitors of human liver aldehyde oxidase was suggested by the resemblance of the phenothiazine structure to that of the known aldehyde oxidase substrate PMS ( $N$-methylphenazine) (Fig. 4). The $N$-alkylphenothiazines studied here are inactive as substrates for the enzyme; this inactivity appears to be due, not to the substitution of sulfur for one of the ring nitrogens, but to the bulky $N$-alkyl side-chains of the phenothiazines tested: $N$-methylphenothiazine, unlike the other members of this group, but like $N$-methylphenazine (PMS), possesses substrate activity for the rabbit liver enzyme. ${ }^{3}$

The $N$-alkylphenothiazines are more potent inhibitors of the human enzyme than of the rabbit enzyme, irrespective of whether benzaldehyde or PMS is used as a substrate (Tables III and IV) : with benzaldehyde $\left(5.7 \times 10^{-5}\right.$ mole per liter $)$ as

\footnotetext{
${ }^{3}$ G. S. Farnham and D. G. Johns. Unpublished data.
} 


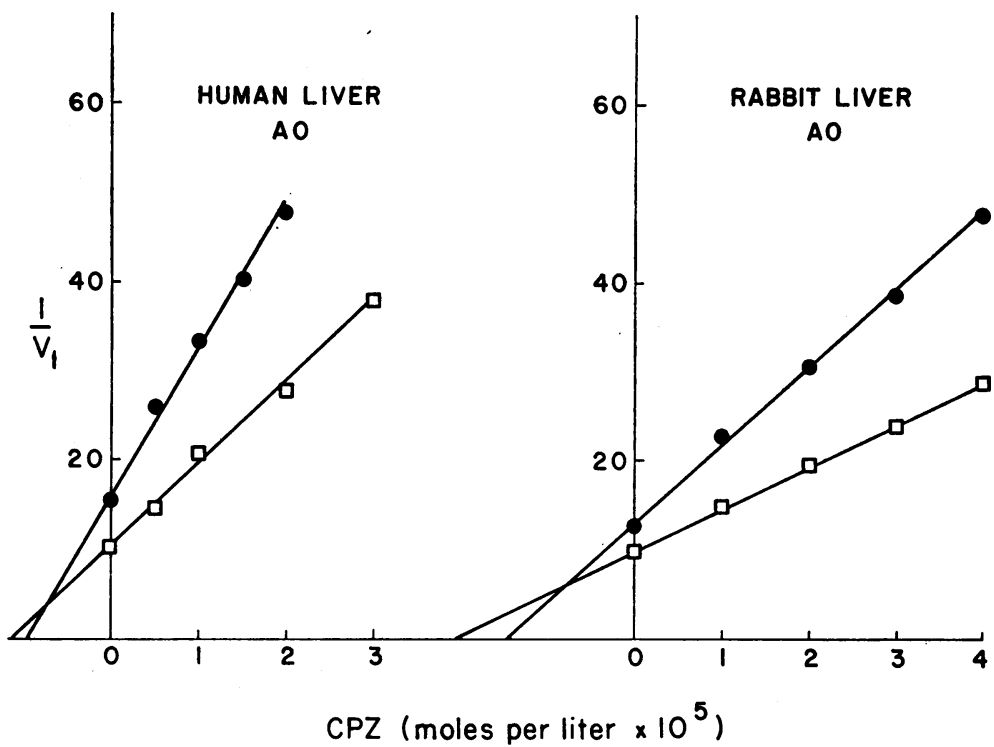

Fig. 5. CoMpetitive INHIBITION BY CHLORPROMAZINE OF OXIDATION OF PMS $\left(5 \times 10^{-4}\right.$ MOLE PER LITER) BY ALDEHYDE OXIDASE FROM HUMAN LIVER AND RABBIT LIVER (DIXON PLOT). Reaction conditions were identical to those given in Table IV. $A O$, aldehyde oxidase; $C P Z$, chlorpromazine.

substrate, the level of chlorpromazine $(\mathrm{CPZ})$ required for $50 \%$ inhibition was $2 \times 10^{-5}$ mole per liter in the case of the rabbit enzyme, but $5 \times 10^{-6}$ mole per liter in the case of the human enzyme. Both with the rabbit and with the human enzyme, $\mathrm{CPZ}$ is formally competitive with substrate (Fig. 5).

(c) Inhibitors of electron transport. Antimycin A, a compound active in mitochondrial systems as an inhibitor at a site subsequent to the reduction

TABLE III

$N$-Alkylphenothiazines as inhibitors of the conversion of benzaldehyde to benzoate by aldehyde oxidase from human liver and rabbit liver*

\begin{tabular}{lcc}
\hline \hline & \multicolumn{2}{c}{ Inhibition } \\
\cline { 2 - 3 } Inhibitor $\ddagger$ & $\begin{array}{c}\text { Human } \\
\text { enzyme }\end{array}$ & $\begin{array}{c}\text { Rabbit } \\
\text { enzyme }\end{array}$ \\
\hline & $\%$ & $\%$ \\
Promethazine & 32 & 53 \\
Promazine & 41 & 63 \\
Trimeprazine & 49 & 85 \\
Chlorpromazine & 51 & 50 \\
Trifluoperazine & 72 & 63 \\
\hline
\end{tabular}

* Control cuvettes contained benzaldehyde, $\mathbf{0 . 0 5 7}$ $\mu$ mole, sodium phosphate buffer, $\mathrm{pH} 7.8,100 \mu$ moles Versene Fe-3, $15 \mu \mathrm{g}$, ammonium chloride, $100 \mu$ moles, and enzyme solution, $0.03 \mathrm{ml}$, in a total volume of $1 \mathrm{ml}$.

$\ddagger$ Inhibitor concentrations were $5 \times 10^{-6}$ mole per liter for assays with human liver aldehyde oxidase, and $2 \times 10^{-5}$ mole per liter for assays with rabbit liver aldehyde oxidase. of coenzyme $Q$ (19), was effective as an inhibitor of benzaldehyde oxidation by human liver aldehyde oxidase (Fig. 6; Table V); the level required was slightly higher than that required to give equivalent inhibition of the rabbit liver enzyme. At low levels of antimycin A, maximal inhibition was not seen until several minutes after the start of the reaction; the rate of onset of inhibition was not increased by preincubation. As with the rabbit enzyme (6), antimycin A may, there-

TABLE IV

$N$-Alkylphenothiazines as inhibitors of the 3-hydroxylation of $P M S$ by aldehyde oxidase from human liver and rabbit liver*

\begin{tabular}{lcc}
\hline \hline \multirow{2}{*}{ Inhibitor $\neq$} & \multicolumn{2}{c}{ Inhibition } \\
\cline { 2 - 3 } & $\begin{array}{c}\text { Human } \\
\text { enzyme }\end{array}$ & $\begin{array}{c}\text { Rabbit } \\
\text { enzyme }\end{array}$ \\
\hline Trifluoperazine & $\%$ & $\%$ \\
Promazine & 30 & 70 \\
Promethazine & 43 & 79 \\
Chlorpromazine & 44 & 62 \\
Trimeprazine & 45 & 48 \\
& 60 & 88
\end{tabular}

* Control cuvettes contained PMS, 0.5 mole, sodium phosphate buffer, pH 7.8, $100 \mu$ moles, Versene Fe-3, $15 \mu \mathrm{g}$, ammonium chloride, $100 \mu$ moles, and enzyme solution, $0.1 \mathrm{ml}$, in a total volume of $1 \mathrm{ml}$

$\mp$ Inhibitor concentrations were $5 \times 10^{-6}$ mole per liter for assays with human liver aldehyde oxidase, and $2 \times 10^{-5}$ mole per liter for assays with rabbit liver aldehyde oxidase. 
TABLE V

Electron transfer inhibitors: relative effectiveness as inhibitors of aldehyde oxidase from human liver and rabbit liver

\begin{tabular}{|c|c|c|c|c|}
\hline \multirow[b]{2}{*}{ Enzyme source } & \multirow[b]{2}{*}{ Substrate } & \multicolumn{3}{|c|}{$\begin{array}{l}\text { Concentration of inhibitor required to reduce reaction rate } \\
\text { to } 50 \% \text { of control rate }\end{array}$} \\
\hline & & Antimycin A & Oligomycin & Amytal \\
\hline $\begin{array}{l}\text { Rabbit liver } \\
\text { Human liver } \\
\text { Rabbit liver } \\
\text { Human liver }\end{array}$ & $\begin{array}{l}\text { Benzaldehyde* } \\
\text { Benzaldehyde* } \\
\text { PMS॥ } \\
\text { PMS॥I }\end{array}$ & $\begin{array}{r}\mu g / m l \\
2 \\
8 \\
2 \\
>40\end{array}$ & $\begin{array}{c}\mu g / m l \\
0.4 \\
>60 \ddagger \\
0.4 \\
>60\end{array}$ & $\begin{array}{l}\text { moles } / \text { liter } \\
3 \times 10^{-4} \\
>3 \times 10^{-4} 8 \\
5 \times 10^{-4} \\
>1 \times 10^{-3}\end{array}$ \\
\hline
\end{tabular}

* Control cuvettes contained benzaldehyde, $0.057 \mu$ mole, sodium phosphate buffer, pH 7.8, $100 \mu$ moles, Versene Fe-3, $15 \mu \mathrm{g}$, ammonium chloride, $100 \mu$ moles, and enzyme solution, $0.03 \mathrm{ml}$, in a total volume of $1 \mathrm{ml}$.

$\ddagger$ Slight inhibition was noted at this concentration (see Table II).

$\$$ Higher Amytal concentrations could not be used because of the absorption of this compound at the wavelength used for the assay $(249 \mathrm{~m} \mu)$.

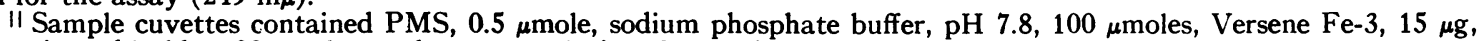
ammonium chloride, $100 \mu$ moles, and enzyme solution, $0.1 \mathrm{ml}$, in a total volume of $1 \mathrm{ml}$.

fore, react with a reduced form of the human enzyme.

By contrast, oligomycin and Amytal, both effective inhibitors of the rabbit liver enzyme (6), were ineffective as inhibitors of human liver aldehyde oxidase (Table V). Slight inhibition of the human enzyme was noted when the oligomycin concentration was raised to $60 \mu \mathrm{g} / \mathrm{ml}$; this concentration, however, is of a different order of magnitude from that required to inhibit the oxidation of benzaldehyde by the rabbit liver enzyme under identical conditions $(0.4 \mu \mathrm{g}$ of oligomycin per $\mathrm{ml})$ (Table V).

(d) Other inhibitors. Cyanide, quinacrine, methanol, $p$-hydroxymercuribenzoate, menadione, and Triton X-100 were effective inhibitors of hu-

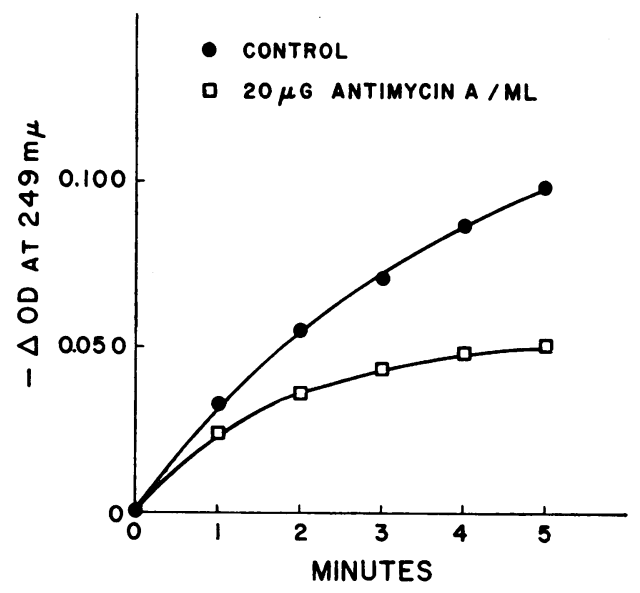

Fig. 6. INHIBITION OF HUMAN LIVER ALDEHYDE OXIDASE BY ANTIMYCIN A. Substrate: benzaldehyde, $5.6 \times$ $10^{-5}$ mole per liter. man liver aldehyde oxidase at levels comparable to those reported for the rabbit liver enzyme (6) (Table II). The iron-chelating agent, $\alpha, \alpha$-dipyridyl, was an effective inhibitor of the oxidation of benzaldehyde by the human enzyme at a concentration of $1 \times 10^{-4}$ mole per liter. 4-Hydroxypyrazolo [3,4- $d]$ pyrimidine $\left(3 \times 10^{-4}\right.$ mole per liter), a highly potent inhibitor of human liver xanthine oxidase (20), was ineffective as an inhibitor of human liver aldehyde oxidase.

(e) Coenzymes. NAD, NADH, NADP, and $\mathrm{NADPH}$ had no effect on the rate of oxidation of benzaldehyde by the 40 - to 60 -fold purified human enzyme. Some oxidation of NADH to NAD was noted in crude fractions; further investigation showed this to be due to the presence of alcohol dehydrogenase, catalyzing the reduction of benzaldehyde to benzyl alcohol. DEAE-cellulose

TABLE VI

\begin{tabular}{lc}
\multicolumn{2}{c}{ TABLE VI } \\
$\begin{array}{l}\text { Aldehydes as substrates for human liver } \\
\text { aldehyde oxidase* }\end{array}$ \\
\hline \multicolumn{2}{c}{$\begin{array}{c}\text { Initial reaction velocity } \\
\text { (Benzaldehyde }=100)\end{array}$} \\
\hline Benzaldehyde & 100 \\
Propionaldehyde & 97 \\
Acetaldehyde & 73 \\
Pyridoxal & 25 \\
o-Chlorobenzaldehyde & 18 \\
$o-$ Nitrobenzaldehyde & $<5$ \\
Formaldehyde & $<5$ \\
\hline
\end{tabular}

* Sample cuvettes contained substrate, $2 \mu$ moles, DCIP, $25 \mu \mathrm{g}$, sodium phosphate buffer, $\mathrm{pH} 7.8,100 \mu$ moles, Versene $\mathrm{Fe}-3,15 \mu \mathrm{g}$, ammonium chloride, $100 \mu$ moles, and enzyme solution, $0.1 \mathrm{ml}$, in a total volume of $1 \mathrm{ml}$. Reaction rates were determined by monitoring the rate of reduction of DCIP, at $600 \mathrm{~m} \mu$. 


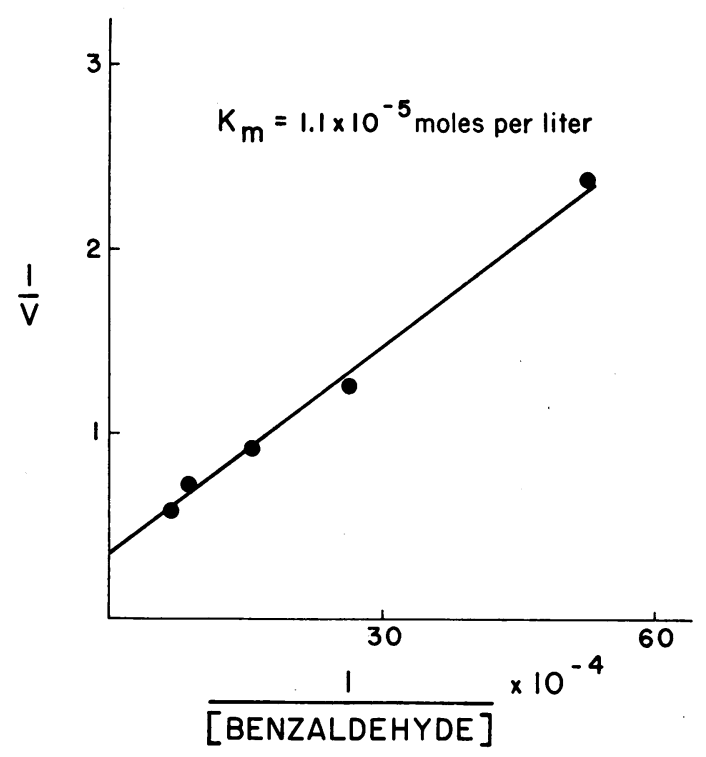

Fig. 7. Oxidation of Benzaldehyde by HuMAN LIVER ALDEHYdE OXIDASE (LINEWEAVER-BURK PLOT). Sample cuvettes contained sodium phosphate buffer, $\mathrm{pH}$ 7.8, $100 \mu$ moles, Versene Fe-3, $15 \mu \mathrm{g}$, ammonium chloride, $100 \mu$ moles, enzyme solution, $0.02 \mathrm{ml}$, and substrate as indicated, in a total volume of $1 \mathrm{ml}$. The rate of oxidation of benzaldehyde was followed by the change in optical density at $249 \mathrm{~m} \mu$.

chromatography separated all alcohol dehydrogenase activity from the aldehyde oxidase preparation.

Added FAD, FMN, and coenzyme $Q_{10}$ did not affect the rate of oxidation of benzaldehyde by the human enzymye.

\section{Other aldehyde substrates}

A number of aliphatic and aromatic aldehydes served as substrates for human liver aldehyde oxidase; in no instance, however, did the maximal reaction velocity exceed that of benzaldehyde (Table VI). The apparent $K_{m}$ of benzaldehyde for the human enzyme, as determined by the Lineweaver-Burk method, was extremely low for this enzyme $\left(1.1 \times 10^{-5}\right.$ mole per liter) (Fig. 7$)$; for other substrates, Michaelis constants ranged from $5 \times 10^{-5}$ to $5 \times 10^{-3}$ mole per liter. Formaldehyde, unlike the other aliphatic aldehydes tested, was an extremely poor substrate for human liver aldehyde oxidase; a similar observation was reported by Palmer (18) for the hog liver enzyme. Early workers (1), using the hog liver enzyme, suggested that the low substrate activity with formaldehyde might be due to denaturation of the enzyme by this compound; this view would not appear to be tenable with human liver aldehyde oxidase, since the oxidation of the substrate PMS by the human enzyme was not significantly inhibited by formaldehyde $\left(6 \times 10^{-3}\right.$ mole per liter $)$, although marked inhibition, as a consequence of competition for the substrate-binding site, was noted in the presence of other aliphatic aldehydes (see below).

\section{Inhibitors of PMS oxidation by human liver al- dehyde oxidase}

It early became apparent from inhibition studies that the mode of PMS oxidation by human liver aldehyde oxidase differed in some important respects from the mode of oxidation of benzaldehyde. Parallel control studies with the rabbit liver enzyme, on the other hand, showed benzaldehyde and PMS to be handled similarly by the latter enzyme.

(a) Inhibitors equally effective against PMS and benzaldehyde oxidation by human liver aldehyde oxidase. Cyanide, quinacrine, $N$-alkylphenothiazines (Tables III and IV), methanol, and

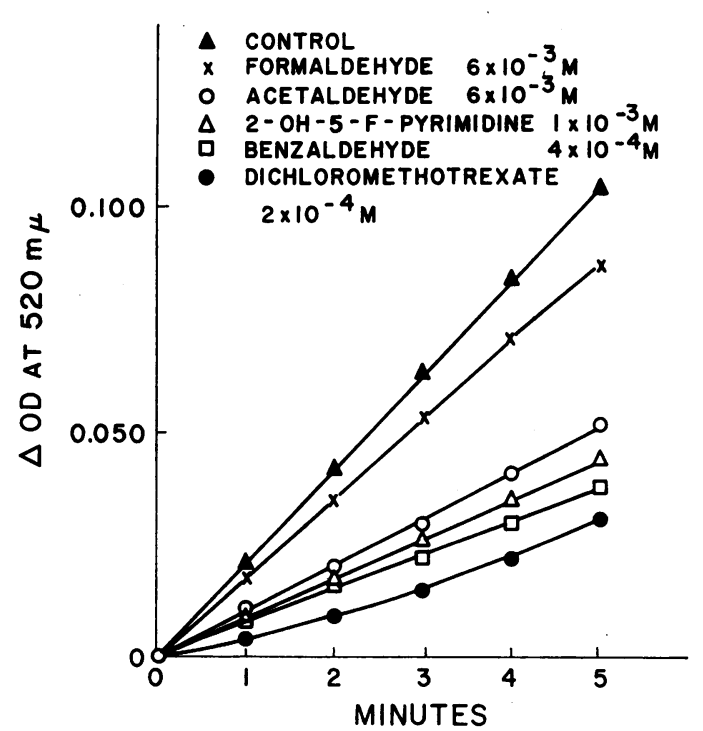

Fig. 8. INHIBITION BY OTHER SUBSTRATES OF OXIDATION OF PMS $\left(5 \times 10^{-4}\right.$ MOLE PER LITER $)$ BY HUMAN LIVER ALDEH YDE OXIDASE. The rate of conversion of PMS to $\mathrm{N}$-methylphenazine-3-one was followed by the change in optical density at $520 \mathrm{~m} \mu$; reaction conditions were identical to those given in Table IV. 
TABLE VII

Estrogens and progesterone as inhibitors of human liver aldehyde oxidase

\begin{tabular}{|c|c|c|c|}
\hline \multirow[b]{2}{*}{ Substrate } & \multicolumn{3}{|c|}{ Concentration of inhibitor required to reduce reaction rate to $50 \%$ of control } \\
\hline & Estradiol-17 $\beta$ & Progesterone & Diethylstilbestrol \\
\hline & \multicolumn{3}{|c|}{ moles/liter } \\
\hline $\begin{array}{l}\text { Benzaldehyde* } \\
\text { PMS } \neq\end{array}$ & $\begin{array}{l}8 \times 10^{-8} \\
1 \times 10^{-4}\end{array}$ & $\begin{array}{r}4 \times 10^{-5} \\
>4 \times 10^{-5}\end{array}$ & $\begin{array}{l}5 \times 10^{-7} \\
\left(8 \times 10^{-6}\right) \S\end{array}$ \\
\hline
\end{tabular}

* Sample cuvettes contained benzaldehyde, $0.056 \mu$ mole, sodium phosphate buffer, $\mathrm{pH} 7.8,100 \mu$ moles, Versene $\mathrm{Fe}-3,15 \mu \mathrm{g}$, ammonium chloride, $100 \mu$ moles, and enzyme solution, $0.03 \mathrm{ml}$, in a total volume of $1 \mathrm{ml}$. Rates were measured $5 \mathrm{~min}$ after the start of the reaction.

$\ddagger$ Sample cuvettes contained PMS, $0.5 \mu$ mole, sodium phosphate buffer, pH 7.8, $100 \mu$ moles, Versene Fe-3, $15 \mu \mathrm{g}$, ammonium chloride, $100 \mu$ moles, and enzyme solution, $0.1 \mathrm{ml}$, in a total volume of $1 \mathrm{ml}$. Rates were measured $5 \mathrm{~min}$ after the start of the reaction.

$\S$ Stimulation, $50 \%$ maximal.

$p$-hydroxymercuribenzoate were equally effective as inhibitors of the oxidation of both PMS and benzaldehyde.

Other substrates for the enzymes, both aldehydes and nonaldehydic heterocyclic substrates, were effective inhibitors of PMS oxidation (Fig. 8 ), a result compatible with utilization of the same substrate-binding site for both aldehyde and nonaldehydic heterocyclic substrates. Benzaldehyde $\left(4 \times 10^{-4}\right.$ mole per liter $)$ was particularly effective as an inhibitor of PMS oxidation. Formaldehyde, as noted above, apparently has low affinity for the substrate-binding site of human liver aldehyde oxidase, as indicated by its very slight ability to inhibit PMS oxidation, shown here, and its low substrate activity (Table VI).

(b) Compounds effective as inhibitors of benzaldehyde oxidation, and ineffective as inhibitors of PMS oxidation by human liver aldehyde oxidase. Menadione, a strikingly effective inhibitor of the oxidation of both benzaldehyde and of PMS by the rabbit liver enzyme, and of benzaldehyde by the human liver enzyme, is ineffective in inhibiting the oxidation of PMS by human liver aldehyde oxidase (Fig. 9). Similarly, the steroid inhibitors (Table VII), Triton X-100 $(5 \times$ $10^{-4} \%$ ), and antimycin A (Table V), highly potent inhibitors of benzaldehyde oxidation, are ineffective as inhibitors of PMS oxidation by the human enzyme.

(c) Compounds effective as inhibitors of benzaldehyde oxidation which stimulate the rate of PMS oxidation by human liver aldehyde oxidase. Diethylstilbestrol, a potent inhibitor of benzaldehyde oxidation by the human enzyme (Table II), stimulates significantly the rate of PMS oxidation
(Fig. 10); the maximal rate reached was $165 \%$ that of the control. Half-maximal stimulation was seen at a diethylstilbestrol concentration of $8 \times 10^{-6}$ mole per liter. Stimulation of PMS oxidation was also noted with the sulfhydryl compound diethyldithiocarbamic acid, a weak inhibitor of benzaldehyde oxidation. The mode of stimulation of PMS oxidation by the two compounds would appear to differ, since the effects were additive when both were added at levels sufficient to give a maximal effect with either compound alone (Fig. 11).

No examples were found of compounds effective as inhibitors of PMS oxidation and ineffective as inhibitors of benzaldehyde oxidation by human liver aldehyde oxidase.

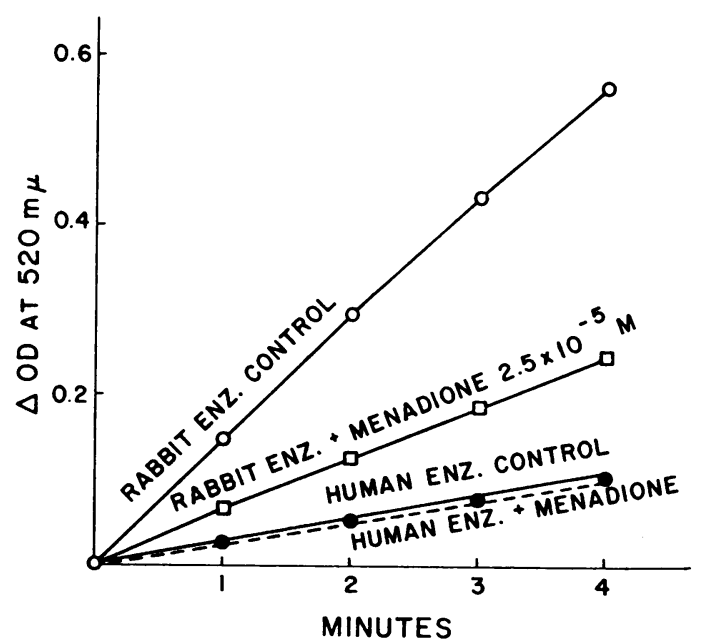

Fig. 9. Differential inhibition By MENAdione $(2.5$ $\times 10^{-5}$ MOLE PER LITER $)$ OF OXIDATION OF PMS $\left(5 \times 10^{-4}\right.$ MOLE PER LITER) BY ALDEHYDE OXIDASE FROM RABBIT LIVER AND HUMAN LIVER. Experimental conditions were identical to those given in Table IV. 


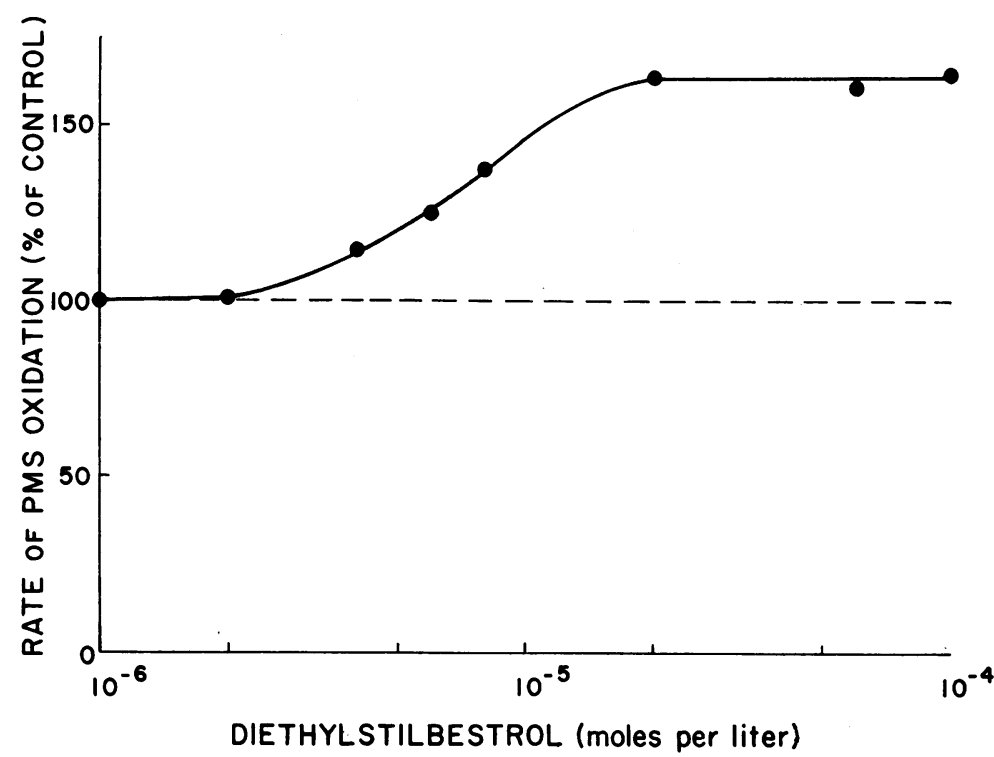

Fig. 10. Stimulation BY Diethylstilbestrol of oxidation of PMS $\left(5 \times 10^{-4}\right.$ MOLE PER LITER) BY HUMAN LIVER ALDEHYDE OXIDASE. Experimental conditions were identical to those given in Table IV. Diethylstilbestrol was added in ethanol solution $(0.01-0.02 \mathrm{ml})$; corresponding volumes of ethanol alone were added to control cuvettes.

\section{Other nonaldehydic heterocyclic substrates}

The oxidation of $N$-methylnicotinamide, which, like PMS, has a positively charged quaternary nitrogen, followed the same pattern as that of PMS,

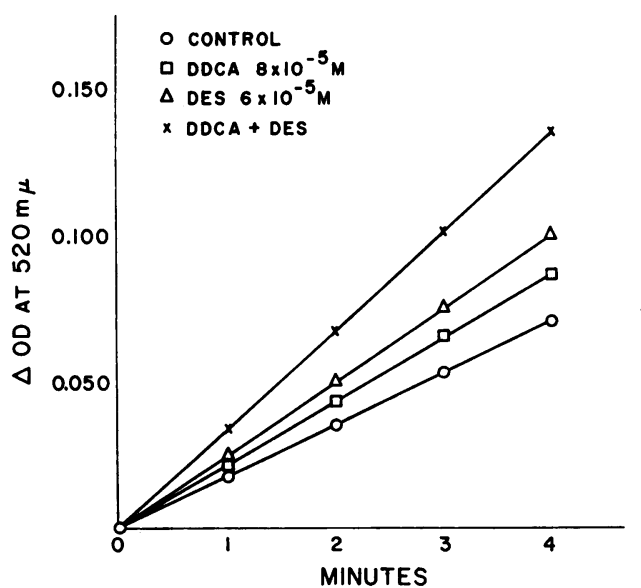

Fig. 11. Additive stimulation By DiethylstilbesTROL, $D E S,\left(2 \times 10^{-5}\right.$ MOLE PER LITER $)$ AND DIETHYLDITHIOCARBAMIC ACID, $D D C A,\left(8 \times 10^{-5}\right.$ MOLE PER LITER $)$ OF OXIDATION OF PMS $\left(5 \times 10^{-4}\right.$ MOLE PER LITER $)$ BY HUMAN LIVER ALDEHYDE OXIDASE. Diethylstilbestrol and diethyldithiocarbamic acid were added in ethanol solution; corresponding volumes of ethanol alone were added to control cuvettes. i.e., the reaction was sensitive to inhibition by cyanide, quinacrine, and $N$-alkylphenothiazines, but not to inhibition by menadione or diethylstilbestrol. In contrast, the oxidation of the uncharged nonaldehydic substrate 2-hydroxy-5-fluoropyrimidine was sensitive to both the latter agents (Table VIII) ; thus, this compound, like benzaldehyde, apparently utilizes the complete "internal electron transport chain" of aldehyde oxidase.

TABLE VIII

Effect of inhibitors on the conversion of 2-hydroxy-5-fluoropyrimidine to 5-fluorouracil by human liver aldehyde oxidase

\begin{tabular}{lcc}
\hline \hline & $\begin{array}{c}\text { Inhibitor } \\
\text { concentration }\end{array}$ & Inhibition \\
\hline & moles/liter & $\%$ \\
Potassium cyanide & $1 \times 10^{-4}$ & 71 \\
Menadione & $2.5 \times 10^{-5}$ & 46 \\
Diethylstilbestrol & $3.3 \times 10^{-5}$ & 93 \\
\hline
\end{tabular}

* Reference cuvettes contained sodium phosphate buffer, $\mathrm{pH} 7.8,500 \mu$ moles, Versene $\mathrm{Fe}-3,20 \mu \mathrm{g}$, ammonium chloride, $600 \mu$ moles, and enzyme, $0.1 \mathrm{ml}$, in a total volume of $3 \mathrm{ml}$. Sample cuvettes contained the same constituents, plus 2-hydroxy-5-fluoropyrimidine, $0.54 \mu$ mole. Ultraviolet absorption spectra were recorded at 20 -min intervals using a Cary 15 recording spectrophotometer with a $0-1.0$ OD slide wire. Reaction rates were determined from the rate of decrease in the absorption maximum of the substrate at $310 \mathrm{~m} \mu$ (11). 


\section{Discussion}

The careful delineation of the "internal electron transport chain" of rabbit liver aldehyde oxidase by Rajagopalan and Handler (6) permits a ready explanation of the results which have been obtained in inhibition studies with the human enzyme. As these authors have demonstrated, cyanide, $p$-hydroxymercuribenzoate, methanol, and quinacrine attack the enzyme at or near the substrate-binding site. The present studies suggest that $N$-alkylphenothiazines, being formally competitive with substrate, also bind at the substrate site, irrespective of whether the rabbit or the human enzyme is used. All these agents are effective in inhibiting the oxidation of either charged or uncharged substrates by the human enzyme. However, a second class of inhibitors, menadione, Triton X-100, antimycin A, and the steroids, apparently influence the reduction and reoxidation of the components of the "internal electron transport chain" of the rabbit enzyme (molybdenum, FAD, coenzyme $Q_{10}$, and iron) and do not bind at the substrate site [Rajagopalan and Handler (6)]. These agents do not affect the oxidation of charged substrates such as PMS and NMN by human liver aldehyde oxidase, but are highly effective inhibitors of the oxidation of uncharged substrates such as benzaldehyde and 2-hydroxy-5fluoropyrimidine, when oxygen is used as electron acceptor. It would appear therefore that, under the conditions used in the present studies, the uncharged substrates for the human enzyme utilize the entire "internal electron transport chain" of the enzyme, and are sensitive to inhibitors which act at any site of the chain, while positively charged substrates can utilize only the substrate site, and are sensitive solely to inhibitors binding at the latter. Thus, whereas with the rabbit enzyme, under aerobic conditions, the electronic structure of the substrate appears to be of little importance in determining the route of electron transport (7), with the human enzyme, the electronic structure of the substrate is of much greater significance.

The present studies do not establish whether molecular oxygen acts as electron acceptor in the oxidation of the charged substrates by the human enzyme, or whether the substrate itself serves this function: Rajagopalan and Handler (13) have shown that, with the rabbit liver enzyme, under anaerobic conditions, PMS can act as an electron acceptor for aldehyde oxidase; and thus, when PMS is used anaerobically as a substrate for the rabbit enzyme, equimolar amounts of $N$-methylphenazine-3-one and leuko PMS are generated. Such a situation may apply with the human enzyme even under aerobic conditions: since the site of electron egress is early in the chain when PMS is used as electron acceptor (6), the insensitivity of PMS oxidation by the human enzyme to electron chain inhibitors such as menadione, which act late in the electron transfer pathway, would thus be accounted for.

The unusual situation of a compound such as diethylstilbestrol acting as either an inhibitor or stimulator of the catalytic activity of an enzyme, depending on which type of substrate is used, is compatible with the two routes of oxidation postulated for human liver aldehyde oxidase. Since diethylstilbestrol and diethyldithiocarbamic acid appear to bind at sites of the internal electron transport chain remote from the substrate-binding site, such compounds could inhibit the oxidation of a compound requiring the complete transport chain (e.g., benzaldehyde) while fortuitously causing a favorable alteration in conformation at the substrate site. Such a favorable conformational change would only be demonstrable when a substrate not requiring the entire electron transport chain, such as PMS, was used.

These studies throw little light on the long standing problem of the metabolic role of aldehyde oxidase. Several other enzymes in addition to aldehyde oxidase are known to possess the ability to catalyze the oxidation of aldehydes, among them xanthine oxidase (EC 1.2.3.2); the steroid-insensitive NAD-linked aldehyde dehydrogenase studied by Racker (21), Deitrich, Hellerman, and Wein (22), and others (EC 1.2.1.3); and the steroid-sensitive NAD-requiring aldehyde dehydrogenase of Maxwell and Topper (23). The studies of Richert and Westerfeld (24) suggest that NAD-linked aldehyde dehydrogenases, rather than metalloflavoproteins such as aldehyde oxidase and xanthine oxidase, are of primary importance in the metabolism of acetaldehyde arising from the oxidation of ethanol. It would appear likely, therefore, that the primary physiologic role of hepatic aldehyde oxidase may 
not be the oxidation of aliphatic aldehydes. From the present studies with the human enzyme, and from earlier studies by other authors with liver aldehyde oxidase from other mammalian species, three other possible functions for this enzyme may be postulated. The first of these is that aldehyde oxidase may be serving a protective function as a nonspecific drug-metabolizing enzyme. It has been shown, for example, that the 7-hydroxylation (and consequent biologic inactivation) of the anti-neoplastic agent methotrexate by this enzyme proceeds so rapidly in the rabbit that, for all practical purposes, a toxic level of this compound for this species cannot be obtained $(25,26)$. Appropriately substituted nonphysiologic purines (12) and pyrimidines (11) can likewise serve as excellent substrates for rabbit liver aldehyde oxidase. The present studies with the human enzyme would tend to suggest, however, that the drug-metabolizing function of aldehyde oxidase is not of importance in all species. In man, the range of nonphysiologic heterocyclic substrates that can be hydroxylated by the enzyme is much narrower than in the rabbit or guinea pig, and the rate of hydroxylation is very much slower.

A second possibility is that these nonphysiologic heterocyclic compounds have the capacity to act as substrates as a consequence of their resemblance to an as yet unidentified physiologic nonaldehydic heterocyclic substrate for the enzyme. The use of aldehyde oxidase inhibitors such as those described in the present paper should permit the testing of this hypothesis: the administration of such an inhibitor at an adequate dosage level should result in an increased urinary excretion of the hypothetical substrate, in the same way that the xanthine oxidase inhibitor 4-hydroxypyrazolo $[3,4-d]$ pyrimidine results in an increased excretion of the xanthine oxidase substrates xanthine and hypoxanthine (27).

The third, and perhaps most likely possibility, is that the physiologic role of human liver aldehyde oxidase is the oxidation of aromatic aldehydes arising from dietary sources, or occurring in the course of intermediary metabolism. As noted above, the aromatic aldehyde benzaldehyde has the highest affinity for the human enzyme of all the substrates examined to date; in addition, the maximal reaction velocity for this substrate exceeded that for all other substrates tested. Similar results were obtained with the mouse and rabbit liver enzymes. Whatever the physiologic role of the enzyme may be, however, the effectiveness as aldehyde oxidase inhibitors of relatively nontoxic pharmacologic agents such as quinacrine and the $N$-alkylphenothiazines, and physiologic compounds such as estradiol-17 $\beta$, would suggest either that aldehyde oxidase, like xanthine oxidase, is not essential to life, or that it is present in great excess over the amount required in intermediary metabolism.

The partial structural analogy between the phenothiazine nucleus and the isoalloxazine component of flavin adenine dinucleotide (FAD) has permitted the hypothesis that $N$-alkylphenothiazines may inhibit flavoproteins in vivo by virtue of an affinity for FAD-binding sites; this suggestion has received experimental support from the observation that $N$-alkylphenothiazines compete with FAD for the apoenzyme of D-amino acid oxidase $(28,29)$. This interpretation, however, cannot be extended to the inhibition by phenothiazines of aldehyde oxidase; in this instance, as the present studies show, the inhibitors are formally competitive with substrate. Similarly, Rajagopalan and Handler (7) have shown that quinacrine inhibits rabbit liver aldehyde oxidase by formal competition with substrate. These results can most easily be interpreted by assuming an affinity of the phenothiazine nucleus (or, in the case of quinacrine, of the rather similar acridine nucleus) for the substrate-binding site of aldehyde oxidase. It would appear, in fact, that only steric hindrance from the long $N$-alkyl side-chains of the phenothiazines examined here prevents these compounds from acting as substrates; as noted above, $N$-methylphenothiazine, like $N$-methylphenazine (PMS), is rapidly oxidized by the rabbit liver enzyme. ${ }^{3}$ Thus, while these studies reveal nothing about the mode of action of the $N$-alkylphenothiazines at the molecular level as psychopharmacologic agents, they permit the alternative suggestion that, assuming these compounds act in vivo as enzyme inhibitors, the site of action at the hypothetical target enzyme or enzymes of the central nervous system may be a substrate-binding site, as with aldehyde oxidase, rather than an FAD-binding site, as with D-amino acid oxidase. It would follow that the hypothetical target enzyme need not be a protein with a readily dissociable flavin cofactor, and that the resemblance between the phenothiazine nucleus 
and the isoalloxazine component of FAD may be fortuitous, and not of pharmacologic significance.

\section{Acknowledgments}

The author would like to thank Mrs. Lucilla Yang for able te hnical assistance, Dr. John Mooney for help in securing fresh normal human liver tissue, and Doctors Joseph Bertino and Brian Hillcoat for helpful discussions. $\mathrm{He}$ is indebted to Dr. David B. Ludlum for pointing out the difference in modes of enzymic oxidation of charged and uncharged substrates.

\section{References}

1. Gordon, A. H., D. E. Green, and V. Subrahmanyan. 1940. Liver aldehyde oxidase. Biochem. J. 34 : 764.

2. Knox, W. E. 1946. The quinine-oxidizing enzyme and liver aldehyde oxidase. J. Biol. Chem. 163: 699.

3. Mahler, H. R., B. Markler, D. E. Green, and R. M. Bock. 1954. Studies on metalloflavoproteins. III. Aldehyde oxidase: a molybdoflavoprotein. $J$. Biol. Chem. 210: 465.

4. Hurwitz, J. 1955. Inhibition studies on aldehyde oxidase. J. Biol. Chem. 212: 757.

5. Rajagopalan, K. V., I. Fridovich, and P. Handler. 1962. Hepatic aldehyde oxidase. I. Purification and properties. J. Biol. Chem. 237: 922.

6. Rajagopalan, K. V., and P. Handler. 1964. Hepatic aldehyde oxidase. II. Differential inhibition of electron transfer to various electron acceptors. J. Biol. Chem. 239: 2022.

7. Rajagopalan, K. V., and P. Handler. 1964. Hepatic aldehyde oxidase. III. The substrate-binding site. J. Biol. Chem. 239: 2027.

8. Loo, T. L., and R. H. Adamson. 1965. The metabolite of $3^{\prime}, 5^{\prime}$-dichloro-4-amino-4-deoxy- $\mathrm{N}^{10}$ methylpteroylglutamic acid (dichloromethotrexate). J. Med. Chem. $8: 513$.

9. Misra, D. K., R. H. Adamson, T. L. Loo, and V. T. Oliverio. 1963. Inhibition of dihydrofolate reductase by dichloromethotrexate and its metabolite. Life Sci. 2 : 407.

10. Johns, D. G., A. T. Iannotti, A. C. Sartorelli, B. A. Booth, and J. R. Bertino. 1965. The identity of rabbit-liver methotrexate oxidase. Biochim. Biophys. Acta. $105: 380$.

11. Johns, D. G., A. C. Sartorelli, J. R. Bertino, A. T. Iannotti, B. A. Booth, and A. D. Welch. 1966. Enzymic hydroxylation of 5-fluoropyrimidines by aldehyde oxidase and xanthine oxidase. Biochem. Pharmacol. 15 : 400.

12. Loo, T. L., C. Lim, and D. G. Johns. 1967. Enzymic hydroxylation of 6-methylthiopurine by hepatic aldehyde oxidase. Biochim. Biophys. Acta. 134: 467.

13. Rajagopalan, K. V., and P. Handler. 1962. Oxidation of phenazine methosulfate by hepatic aldehyde oxidase. Biochem. Biophys. Res. Commun. 8: 43.

14. Singer, T. P., and E. B. Kearney. 1957. Determination of succinic dehydrogenase activity. Methods Biochem. Analy. 4: 307.

15. Waddell, W. J. 1956. A simple ultraviolet spectrophotometric method for the determination of protein. J. Lab. Clin. Med. $48: 311$.

16. Carpenter, F. H. 1951. Studies on the purification and properties of aldehyde oxidase from horse liver. Acta Chem. Scand. 5: 406.

17. Igo, R. P., B. Mackler, and H. Duncan. 1961. Liver aldehyde oxidase: the nature of hematin component. Arch. Biochem. Biophys. 93: 435.

18. Palmer, G. 1962. The purification and properties of aldehyde oxidase. Biochim. Biophys. Acta. 56: 444.

19. Pumphrey, A. M., and E. R. Redfearn. 1959. The rate of reduction of the endogenous ubiquinone in a heart-muscle preparation. Biochem. J. 72:2P.

20. Watts, R. W. E., J. E. M. Watts, and J. E. Seegmiller. 1965. Xanthine oxidase activity in human tissues and its inhibition by allopurinol (4-hydroxypyrazolo (3,4-d) pyrimidine). J. Lab. Clin. Med. $66: 688$.

21. Racker, E. 1949. Aldehyde dehydrogenase, a diphosphopyridine nucleotide-linked enzyme. J. Biol. Chem. $177: 883$.

22. Deitrich, R. A., L. Hellerman, and J. Wein. 1962. Diphosphopyridine nucleotide-linked aldehyde dehydrogenase. I. Specificity and sigma-rho function. J. Biol. Chem. $237: 560$.

23. Maxwell, E. S., and Y. J. Topper. 1961. Steroidsensitive aldehyde dehydrogenase from rabbit liver. J. Biol. Chem. 236: 1032.

24. Richert, D. A., and W. W. Westerfeld. 1957. Acetaldehyde oxidation in molybdenum deficiency. $J$. Biol. Chem. 227 : 533.

25. Redetzki, H. M., J. E. Redetzki, and A. L. Elias. 1966. Resistance of the rabbit to methotrexate: isolation of a drug metabolite with decreased cytotoxicity. Biochem. Pharmacol. 15 : 425.

26. Johns, D. G., and T. L. Loo. 1967. Metabolite of 4-amino-4-deoxy- $\mathrm{N}^{10}$-methylpteroylglutamic acid (methotrexate). J. Pharm. Sci. 56: 356.

27. Rundles, R. W., J. B. Wyngaarden, G. H. Hitchings, G. B. Elion, and H. R. Silberman. 1963. Effects of a xanthine oxidase inhibitor on thiopurine metabolism, hyperuricemia, and gout. Trans. Assoc. Am. Physicians. 76: 126.

28. Gabay, S., and S. R. Harris. 1965. Studies of flavin adenine dinucleotide-requiring enzymes and phenothiazines. I. Interactions of chlorpromazine and D-amino acid oxidase. Biochem. Pharmacol. $14: 17$.

29. Gabay, S., and S. R. Harris. 1966. Studies of flavin-adenine dinucleotide-requiring enzymes and phenothiazines. II. Structural requirements for D-amino acid oxidase inhibition. Biochem. Pharmacol. 15: 317. 